\title{
The Use Social Media and Employee Performance in MSMEs Development: Glass Noodle Home Industry Manjung Indonesia
}

\author{
Achmad Zainul Rozikin ${ }^{1^{*}}$, Setyabudi Indartono ${ }^{2}$, Sugiharsono $^{3}$ \\ 1,2,3 Universitas Negeri Yogyakarta, Indonesia \\ Iachmad_zr.2017@student.uny.ac.id, ${ }^{2}$ setyabudi_indartono@uny.ac.id, ${ }^{3}$ sugiharsono@uny.ac.id, ${ }^{*}$ corresponding author
}

\begin{abstract}
The alternative to developing a business is to use social media optimally supported by optimal employee performance. The purpose of this study is to determine the effect of social media on business development in the glass noodles Manjung Home Industry through employee performance. This research is included as causal associative research. Data on social media variables and employee performance are taken using questionnaires, while business development variables are taken using documentation. This research uses path analysis method. The results of this study indicate that social media influences employee performance; social media influences business development, and employee performance influence on business development. However, in this study employee performance variables are not considered as intervening variables due to its smaller contribution on direct business development compared to influence of social media.
\end{abstract}

Keywords: business development, employee performance, MSMEs, social media

\section{Penggunaan Media Sosial dan Kinerja Karyawan Terhadap Perkembangan UMKM: Home Industry Mie Soun Manjung Indonesia}

\begin{abstract}
Abstrak: Salah satu alternatif untuk mengembangkan suatu usaha ialah dengan pemanfaatan media sosial secara optimal serta didukung dengan kinerja karyawan optimal juga. Tujuan penelitian ini adalah untuk mengetahui pengaruh media sosial terhadap perkembangan usaha pada Home Industry mie soun Manjung melalui kinerja karyawan. Penelitian ini termasuk dalam penelitian asosiatif kausal. Data pada variabel media sosial dan kinerja karyawan diambil dengan menggunakan angket, sedangkan variabel perkembangan usaha diambil dengan menggunakan dokumentasi. Penelitian ini menggunakan metode analisis jalur. Hasil penelitian ini menunjukkan bahwa terdapat pengaruh media sosial terhadap kinerja karyawan, pengaruh media sosial terhadap perkembangan usaha, dan yang terakhir pengaruh kinerja karyawan terhadap perkembangan usaha. Namun, dalam penelitian ini variabel kinerja karyawan tidak dianggap sebagai variabel intervening, karena sebagai variabel intervening, kinerja karyawan memiliki kontribusi yang lebih kecil daripada pengaruh media sosial terhadap perkembangan usaha secara langsung.
\end{abstract}

Kata kunci: perkembangan usaha, kinerja karyawan, UMKM, media sosial

\section{INTRODUCTION}

The existence of MSMEs is important in a country (Yilmaz, 2009). MSMEs contribute to the country by creating jobs, technological innovation and economic income (Bonito and Pais, 2018). The existence of MSMEs cannot be doubted because it is proven to be able to survive and become the economic driving force. MSMEs can also make a large contribution to job creation (Chen, 2006).

Extensive job creation will occur if MSMEs in an area have increased. As shown in Table 1, it shows that MSMEs in Central Java Province in the 4th Quarter of 2017-2018 increased from 0.12 percent to 4.34 percent. 
Jurnal Economia, 15(2), Oktober 2019, 221-231

Table 1. Growth of Central Java Micro and Small Enterprises in Quarter IV of 2017 and

\begin{tabular}{ccc} 
& \multicolumn{2}{c}{2018.} \\
\cline { 2 - 3 } Region of Growth & \multicolumn{2}{c}{ Growth (Percent) } \\
\cline { 2 - 3 } & \multicolumn{2}{c}{ y-on-y } \\
\hline Central Java & Quarter IV 2017 & Quarter IV 2018 \\
\hline
\end{tabular}

Source: BPS 2018

Although overall it experienced an increase, the decline occurred in the aspect of the food industry. As shown in table 2, it shows that the food industry in Central Java Province in the fourth quarter of 2017-2018 decreased from 2.31 percent to -8.27 percent.

Table 2. Growth in the Food Industry in Central Java Province Quarter IV 2017 and

\begin{tabular}{ccc}
\multicolumn{2}{c}{2018.} \\
\hline \multirow{2}{*}{ Type of Industry } & \multicolumn{2}{c}{ Growth (Percent) } \\
\cline { 2 - 3 } & \multicolumn{2}{c}{ y-on-y } \\
\cline { 2 - 3 } Food industry & Quarter IV 2017 & Quarter IV 2018 \\
\hline
\end{tabular}

Source: BPS 2018

The decline in the growth of the food industry is influenced by many factors as well as the general problems faced by most MSMEs, namely the quality of human resources is less qualified in business development, and the marketing and sales systems are still conventional (Diartono et al., 2015). Sudaryanto and Hanim (2002) also mention that the problems faced by MSMEs include limited capital, poor quality human resources, and lack of technology knowledge. Another problem faced and at the same time is the weakness of MSMEs is the lack of access to information, especially market information.

Based on the observations I made at the glass noodle industrial MSMEs center in Manjung village, Klaten Regency, the problem is that the marketing strategy is still traditional, not yet popular, there has been no research or development from the government or universities, still traditional production tools and employee performance is not optimal, motivation work is still not optimal. In marketing, it is still very simple, namely by visiting customers directly and bringing samples of their products, so it is not efficient.

This simple marketing strategy makes entrepreneurs spend more money and energy. They must go out of town first to offer their products to consumers directly. With this marketing model, employee performance (marketing) and company performance become inefficient. So that the company's development is hampered.

MSMEs entrepreneurs should use information technology to access information needed especially about markets (Dietz et al., 2003). Information technology itself is currently the primary need of a company because it is to develop its business (Warmayana, 2018). Information technology has also influenced and changed the way business is currently being managed and monitored. Information technology is often used in the form of social media. 
Social media is very appropriate to be used to market products effectively and efficiently (Solekhan \& Winarso, 2016). Because with the presence of social media, entrepreneurs can easily market their products (Morrison, 2007). The use of social media can also create new opportunities and as a medium of communication with customers (Jantsch, 2010). The use of social media must also be supported by good employee performance.

Employee performance is also thought to influence the development of a company. Its role in the company can determine the company's future and as a determinant of success over a long period of time (Margaretha, 2012). Employee performance will be more productive if aspects of him are considered by the company. These aspects include the quality, skills, and responsibilities (Suprihati, 2014). An employee is expected to be able to increase work productivity optimally (As'ad, 2001: 22). When the employee's performance is high quality, productivity will increase and the company will easily develop.

In fact, in the home industry of glass noodle, the performance of its employees is still not optimal. The lack of optimal performance of employees in the glass noodle industry can be seen from the number of times they produce glass noodles. Ideally, the company can produce glass noodles four times a day, but most of them are only able to produce two to three times a day. In addition, the tools used to produce are still traditional.

According to the World Bank, MSMEs are a business that fulfills two of three criteria, namely employee strength, annual asset size or sales (Das, 2017). Meanwhile, according to Simmons, Armstrong \& Durkin (2008) MSMEs are a business that only has a small market scope, a small workforce, and is managed by the business owner.

Business development is an income increase (turnover) of sales from a company (Chandra, 2000). Business development not only increases income, but also increases volume, profits, and labor (Jennings et al. 1997). Business development is the management growth and economic competitiveness of the company (Ayodeji et al., 2015). Increasing this competitiveness will have a positive impact on the company. Companies will get more income so they can survive and even compete with other companies.

Business development is usually seen in terms of income (turnover) received every month. According to Inggarwati and Kaudin (2010),) business development can be measured by looking at sales growth, increasing employees, increasing profits, and increasing asset values. If all this has been realized, then the business can be considered experiencing development.

A company will experience development because there are several factors, namely entrepreneurial characteristics, employee performance, business capital, and marketing strategies (Purwanti, 2012). Capital is a major factor in building and developing a business. Capital is considered as the foundation of business because the size of the business depends on the capital owned by the entrepreneur.

Meanwhile, the Resources Based View theory explains about the resources that exist within the company (Fahy, 2000). The progress and decline of a company is influenced by the strengths and weaknesses of the company's resources (Paulus and Murdapa, 2016). The company's progress is influenced by its resources and the capability of the company that can 
transform these resources into an economic advantage for the company (Ferreira et al., 2011), so that it can contribute to the company's sustainable competitive advantage (Lacity and Willcocks, 2008).

Performance is the result obtained by someone when completing the tasks assigned to him based on skills, experience, and timeliness in completing it (Hasibuan, 2008). Performance can also be interpreted as the result of one's work which is seen from the quality and quantity when carrying out their duties in accordance with the responsibilities he carries (Mangkunegara, 2009). Sarmiento et al. (2007) argue that employee performance has two aspects, namely the ability and skills (natural or acquired) that employees have, and their motivation is used to do the job better.

Indicators to measure employee performance are as follows: job performance, productivity, safety, quality of care delivered, errors, adverse events and client satisfaction (Dall'Ora, 2016). Whereas according to Soedjono (2005) dividing employee performance indicators such as quality, quantity, timeliness, effectiveness, independence, work commitment, and having a sense of responsibility. Osman et al. (2016) state that employee performance can be measured using indicators of competence, motivation, discipline, and teamwork.

Employee performance has a positive relationship with business development. Good employee performance will create high effectiveness (Steers and Portter, 1977: 9). High effectiveness illustrates that the performance of a company is progressing and developing. Because with high effectiveness, the costs incurred will be reduced.

Uses and Gratifications Theory was first developed in the 1940s during a study of the use of radio media by the public (Li et al., 2015). This U\&G approach focuses on identifying the psychological needs of individuals who are motivated to use certain media (Li et al., 2015). This explains why someone uses certain media to satisfy their various needs. So that it can be interpreted that according to the U\&G approach, someone uses a media according to their needs.

Social media is an online network whose influence is most powerful because it has been integrated into social and economic life in the real world (Zeng \& Gerritsen, 2014). In business, the use of social media will increase brand awareness, communication with consumers, efficient marketing, show company expertise, and get more business contacts (McCann et al., 2015).

Based on the problems discussed above, we can discuss the factors that influence the development of home industry glass noodles Manjung, Klaten Regency, Indonesia. The author aims to find evidence about social media on business development in the glass noodles Manjung Home Industry through employee performance. This study uses path analysis and data analysis using SPSS 21 with three variables (social media, employee performance, and business development), while data obtained from 55 entrepreneurs.

\section{METHOD}

This study uses a path analysis method which is used to determine the relationship of the dependent variable with the independent variable. Path analysis was conducted to 
determine the magnitude of the indirect influence of independent variables (social media (X)) on the dependent variable (business development (Y2)) through intervening variables (employee performance (Y1)). And whether the independent variable has significant influence or not. With the $\mathrm{H} 0$ criterion rejected if the probability value of each variable is less $5 \%$ (sig. $<0.05$ ).

This analysis is useful for finding path coefficients. Path coefficients are actually standardized regression coefficients. Path coefficient is a standard regression coefficient (beta) that shows the effect of independent variables on the dependent variable that has been arranged in a path diagram. If there are two or more variables in the path diagram, then the par coefficient can be calculated.

This research is causal associative research because it wants to know the causal relationship of variables that influence and variables that are affected (Sugiyono, 2013: 59). The instrument in this study adopted a research instrument that had been developed by previous researchers in which all answers to questions would be measured in five scores using an ordinal scale of 4 Likert points, starting from strongly agree (point 4) to strongly disagree (point 1). In the variable business development, data is taken using documentation and data in the form of income per month from 2017 - 2018. The unit of analysis of this study is individuals. This means that the research respondents who are samples represent themselves.

The population who were the subjects of this study were 55 people of Manjung glass noodle entrepreneur. Retrieval of data in this study using population data. The data used in this study is primary data obtained directly from respondents by providing questionnaires that will be filled by respondents (Sekaran, 2006).

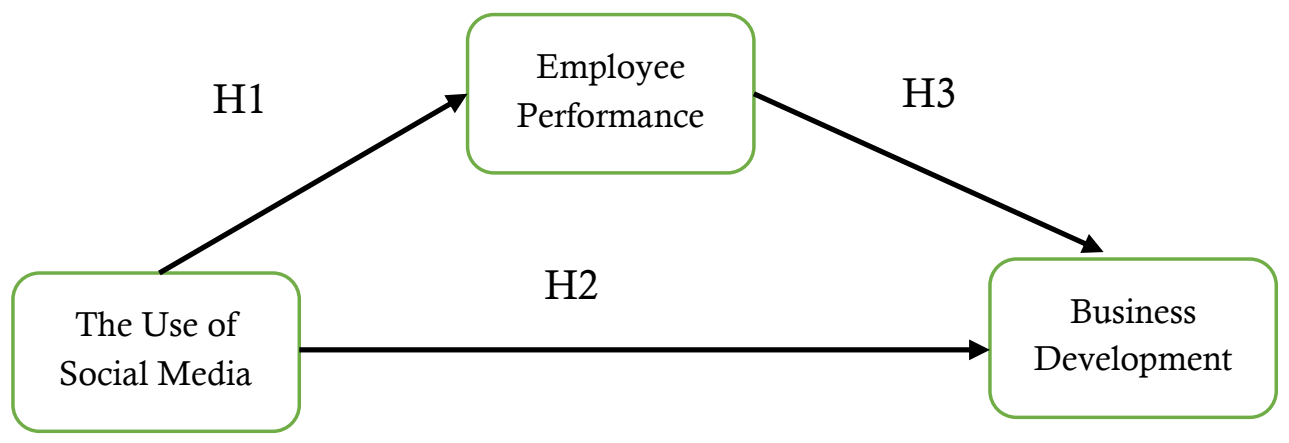

Figure 1. Research Model

Statistical testing aims to test the predictive effects between latent variables to see whether there is a relationship or influence between variables called prediction models. The use of this prediction model has its own consequences, namely, testing can be done without a strong theoretical basis, ignoring some assumptions, and the accuracy parameters of the prediction model seen from the coefficient of determination (R2). For this reason, the prediction model is very appropriate for research aimed at developing theory. 


\section{FINDING AND DISCUSSION}

A total of 55 respondents filled out the research questionnaire. The composition of respondents was dominated by men, which amounted to $69 \%$, while the latter education was dominated by high school graduates by $65 \%$. This composition shows that the population that became the respondent was Manjung glass noodle entrepreneur.

Based on Table 3, the value of the social media variable path coefficient $(\mathrm{X})$ on employee performance $\left(\mathrm{Y}_{1}\right)$ is $\mathrm{pXY} \mathrm{Y}_{1}=0,572$. Coefficient or contribution (Adjusted $\mathrm{R}$ Square $\left.=\mathrm{R}_{\mathrm{XY} 1}^{2}\right)=0,315$. Thus, the amount of the residual coefficient $\rho \mathrm{Y}_{1} \varepsilon_{1}=\sqrt{1-0,315}=0,827$. Table 3 also shows the value of the social media variable path coefficient $(X)$ on business development $\left(\mathrm{Y}_{2}\right)$ of $\mathrm{pXY}=0,516$ and the variable path coefficient value of employee performance $(\mathrm{Y} 1)$ is $\mathrm{pY}_{1} \mathrm{Y}_{2}=0,348$. Coefficient or contribution (Adjusted $\mathrm{R}$ Square $=$ $\mathrm{R}_{\mathrm{XY1Y2}}^{2}=0,577$. Thus, the amount of the residual coefficient $\rho \mathrm{Y}_{2} \varepsilon_{2}=\sqrt{1-0,577}=0,650$.

Table 3. Probit Regression

\begin{tabular}{|c|c|c|c|c|}
\hline Variable & $\begin{array}{c}\begin{array}{c}\text { Standardized } \\
\text { Coefficients }\end{array} \\
\text { Beta }\end{array}$ & $\mathrm{T}$ & $\begin{array}{l}\text { Adjusted R } \\
\text { Square }\end{array}$ & Signifikansi \\
\hline $\begin{array}{l}\text { Sosial Media } \\
\text { (X) }\end{array}$ & 0,572 & 5,079 & 0,315 & 0,000 \\
\hline \multicolumn{5}{|c|}{ Dependent Variable: Employee Performance $\left(\mathrm{Y}_{1}\right)$} \\
\hline $\begin{array}{l}\text { Social Media } \\
\text { (X) }\end{array}$ & 0,516 & 4,777 & & 0,000 \\
\hline Employee & & & 0,577 & \\
\hline $\begin{array}{c}\text { Performance } \\
\left(\mathrm{Y}_{1}\right)\end{array}$ & 0,348 & 3,223 & & 0,002 \\
\hline
\end{tabular}

Based on the results of the path coefficients in structure 1 and structure 2, it can be described as a whole which illustrates the empirical causal relationship between variables $\mathrm{X}$ to variables $Y_{1}$ and $Y_{2}$ (see Figure 2).

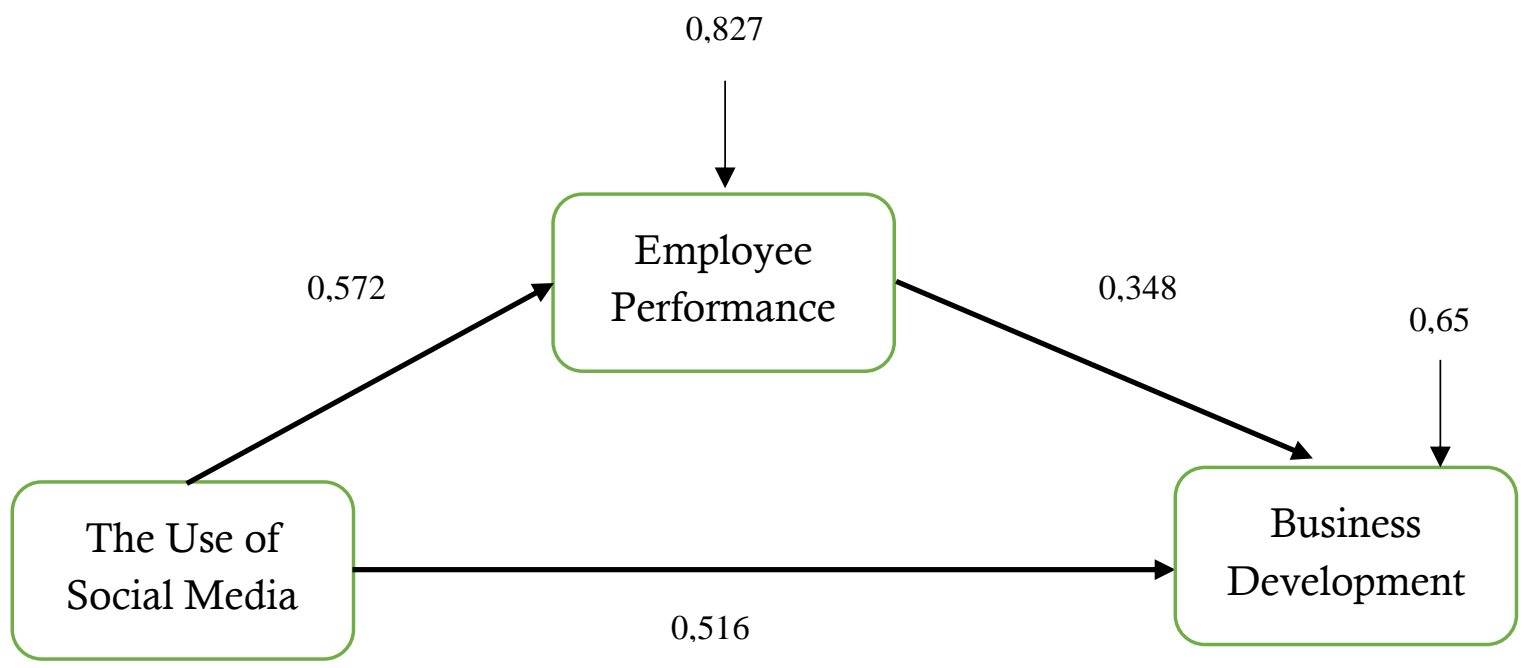

Figure 2. Research Result 
The path coefficient results in structure 1 and structure 2 when written in the equation to be:

$$
\begin{aligned}
\mathrm{Y}_{1} & =\mathrm{PY}_{1} \mathrm{X}+\mathrm{PY}_{1} \varepsilon_{1} \\
& =0,572 \mathrm{X}_{1}+0,827 \varepsilon_{1}=0,315 \\
\mathrm{Y}_{2} & =\mathrm{PY}_{2} \mathrm{X}+\mathrm{PY}_{2} \mathrm{Y}_{1}+\mathrm{PY}_{2} \varepsilon_{2} \\
& =0,516 \mathrm{X}+0,348 \mathrm{Y}_{1}+0,65 \varepsilon_{2}=0,577
\end{aligned}
$$

Based on the results of the overall calculation, it can provide objective information as follows: (1) In structure 1 the results of the analysis found that information that social media contributes significantly to employee performance. The amount of the contribution is $32.7 \%$; (2) In structure 2, the results of the analysis are found which provide information that social media contributes significantly to business development. The amount of the contribution is $26.6 \%$; (3) In structure 2, the results of the analysis are found which provide information that employee performance contributes significantly to business development. The amount of the contribution is $12.1 \%$; (4) The size of the contribution of social media and the effect of employee performance simultaneously which directly affects business development is $0.577=57.7 \%$ and the remaining $42.3 \%$ is influenced by other factors that cannot be explained in research; (5) The amount of social media contributions indirectly affects business development through employee performance by $19.9 \%$.

From the results of these calculations, the magnitude of the contribution of employee performance variables as intervening variables is smaller than social media variables that directly influence business development. So that employee performance variables cannot be used as intervening variables, but are made as independent variables.

In this study, it was investigated that the use of social media and employee performance affected business development, the results were quite significant. In improving employee performance, the use of social media also affected it significantly. Evidenced by the use of social media optimally will be able to form employee social capital, vision, and mutual trust and in turn, can be a facility for knowledge transfer (Cao, et al., 2016). The shared vision and transfer of knowledge will affect the performance of the employee.

The use of social media can also improve the skills of employees, gain knowledge, increase motivation to work so that work is more productive (Ashraf, 2014). This is all because social media has a source of knowledge that is easy to find. In addition, on social media, there is also a variety of information that helps someone to be more creative or skilled. Social media not only affects employee performance but also influences business development.

In business development, the use of social media will provide a competitive advantage for MSME entrepreneurs, provide a brand image for MSMEs, and MSME is not considered a peripheral company (Iswanto, 2013). In addition, social media has an important role in many aspects of the company, such as information seeking, promotion, and dealing with customers (Zeng \& Gerritsen, 2014). With the use of social media optimally, it can also be used as a tool for marketing, reducing costs, and can increase profits (Basri, 2016). McCann et all., (2015) also states that in business, the use of social media will 
increase brand awareness, communication with consumers, efficient marketing, show company expertise, and get more business contacts.

In business development, the most important factor is the performance of the employees of a company. Every employee is a valuable asset for a company. Therefore, companies must first pay attention to their employees, because the success or failure of a company is influenced by the performance of employees (Hameed and Waheed, 2011). Therefore, the company must pay attention to the factors that influence it. Factors that can influence performance are worker knowledge, quality, and quantity of output, leadership, cooperation (Zameer et al., 2014). Whereas according to Suprihati (2014) several factors can affect employee performance, namely the existence of training, incentives, and work environment. If most of the employee's needs are met, then their performance will increase and affect the development of the company (Sugiharsono, 2008).

In accordance with the theory put forward by Maslow (1943) that humans have five levels of needs (actualization needs, expectations, social needs, needs for security, and physiological needs). If this need is achieved, then humans will be more motivated to carry out an activity. As is the case with employees, if employee needs are met properly, then the employee will be more motivated to work and will influence their performance. So, with high motivation, the employee's performance will be high.

With high employee performance, this will also affect the productivity of the company. Because employees are one of the company's resources, this statement is per the $\mathrm{RBV}$ theory which states that the progress or deterioration of a business is influenced by the resources possessed (Paulus and Murdapa, 2016). The productivity of employee performance will make the costs incurred by the company to be more effective and efficient. This cost-effective will make the company get a profit that is more updated usually. They will experience growth and can even experience development.

\section{CONCLUSION}

This study resulted in the finding that the use of social media and employee performance had an influence on business development. In this study, the indirect effect of using social media on business development through employee performance has a smaller contribution than direct influence. So it can be concluded that employee performance variables cannot be used as intervening variables, but can only be used as independent variables.

The use of social media correctly and optimally will be able to improve a person's performance, including employers and employees. Because on social media there is a lot of information available that can foster creativity, insight, and knowledge of a person. With the increase in creativity, knowledge, and knowledge of employers and employees, it will have an impact on their performance.

The use of social media can also increase a company's income because social media can be used for marketing. Marketing through social media can save costs and energy. On social media, marketing is only enough to post pictures of products sold along with information. By using social media, the market scope of the company is also increasingly widespread, because the use of social media is not limited by space and time. The expansion 
of the glass noodle home industry market will have an impact on increasing sales and will make the company grow.

Business development is not only influenced by the use of social media but must be supported by the performance of qualified employees. Employee performance is a key factor in the success or failure of a business. Therefore, companies need to pay attention to the performance of their employees. Employees need to be nurtured and trained so that they are more creative, more motivated, and more active. If employees are motivated, creative and active, their performance will be more productive and will have an impact on increasing the company's income.

\section{ACKNOWLEDGEMENT}

Sincerely, the researchers thank the lecturers who have guided the authors on a regular basis. Also thanks to colleagues who have provided constructive encouragement and criticism. So that this article can be completed correctly and on time.

\section{REFERENCES}

As'ad, M. (2001). Kepemimpinan efektif dalam perusahaan edisi ke-2. Yogyakarta: Liberty.

Ashraf, N. (2014). Impact of social networking on employee performance. Business Management and Strategy, 5(2).

Ayojedi, I. O., Lasisi, Adebay0, F. (2015). Role of mentoring in business development in Nigeria. Global Journal of Human Resource Management, 3(3), 17-38.

Basri, W. (2016). Social media impact on small and medium enterprise: case review of businesses in the Arab World. Arts and Social Sciences Journal, 7(6), 1-5. https://doi.org/10.4172/2151-6200.1000236.

Cao, X, Guo, X., Vogel, D., \& Zhang, X. (2016). Exploring the influence of social media on employee work performance. Internet Research, 26(2), 529-545.

Chandra, P. E. 2000. Trik sukses menuju sukses. Yogyakarta: Grafika Indah.

Dall'Ora, C., Ball, J., Recio-Saucedo, A., \& Griffiths, P. (2016). Characteristics of shift work and their impact on employee performance and wellbeing: A literature review. International Journal of Nursing Studies, 57, 12-27. doi:10.1016/j.ijnurstu.2016.01.007.

Das, P. (2017). Micro, small and medium enterprises (MSME) in India: Opportunities, issues \& challenges. Great Lakes Herald, 11(1), 77-88.

Dietz, T, Ostrom, E., and Stern, P. C. (2003). The struggle to govern the commons. Science 302, 1907-1912.

Ferriera, J.J., Azevedo, G.S., dan Fernandez, R. (2011). Contribution of resource based view and entrepreneurial orientation on small firm growth. Cuadernos de Gestin, 11(1), 95-104.

Hameed, A. \& Waheed, A. (2011). Employee Development and Its Affect on Employee Performance A Conceptual Framework. International Journal of Business and Social Science, 2(13), 224-229.

Hasibuan, M. (2008). Manajemen sumber daya manusia. Jakarta: CV. Haji Masagung. 
Inggarwati, K., \& Kaudin, A. (2010). Peranan faktor-faktor individual dalam mengembangkan usaha. Jurnal Manajemen Bisnis, 3(2), 185-202.

Iswanto, T. (2013). Optimalisasi sosial media sebagai media pemasaran usaha kecil menengah. Jurnal Liquidity, 2(1), 80-86.

Jantsch, J. (2010). Let's Talk: Social media for small business. Vol. 2. Redmond, WA: Microsoft.

Jennings, P., \& Beaver, G. (1997). The Performance and competitive advantage of small firms: A management perspective. International Small Business Journal, 15(2), 63-75. DOI: $10.1177 / 0266242697152004$.

Lacity, M. C. \& Willcocks, L. (2008). Information systems and outsourcing: studies in theory and practice, Palgrave Macmillan.

Li, H., Liu, Y., Xu, X., Heikkilä, J., dan Heijden, H. V. D. (2015). Modeling hedonic is continuance through the uses and gratifications theory: An empirical study in online games. Computers in Human Behavior, 48, 261-272. https://doi.org/10.1016/j.childyouth.2016.11.005.

Mangkunegara, A.A. Anwar Prabu. (2009). Manajemen sumber daya manusia perusahaan. Bandung: Remaja Rosdakarya.

Margaretha, M. (2012). Pengaruh Sikap Kerja Terhadap Kinerja Karyawan pada PT. Duta Marga Silima di Jakarta, Jurnal Manajemen dan Bisnis, 2(2), 151-166.

Maslow, A.H. (1943). A Theory of Human Motivation. Psycological Review, 50(4), 370-396.

McCann, M., \& Barlow, A. (2015). Use and measurement of social media for SMEs. Journal of Small Business and Enterprise Development, 22(2), 273-287. doi:10.1108/jsbed-082012-0096.

Morrison. (2007). Periklanan komunikasi pemasaran terpadu. Jakarta: Ramdina Perkasa.

Osman, S., Shariff, S. H., \& Lajin, M. N. A. (2016). Does innovation contribute to employee performance? Procedia-Social and Behavioral Sciences, 219, 571-579.

Paulus, A. L. \& Murdapa, P. S. (2016). Pemanfaatan teori resource-based view pada ritel minimarket: implikasinya terhadap strategi dan keunggulan bersaing. Jurnal Riset Ekonomi dan Manajemen, 16(2), 215-224.

Purwanti, E. (2012). Pengaruh karakteristik wirausaha, modal usaha, dan strategi pemasaran terhadap perkembangan UMKM Di Desa Dayaan dan Kalilondo Salatiga. Jumal Ilmiah Among Makarti, 5(9), 13-28.

Sarmiento, R., Beale, J. \& Knowles, G. (2007). Determinants of performance amongst shop-floor employees: a preliminary investigation. Management Research News, 30(12), 915-927.

Sekaran, U. (2006). Research Method Business. Hermitage Publishing Services

Simmons, G., Armstrong, G. A., \& Durkin, M. G. (2008). A Conceptualization of the Determinants of Small Business Website Adoption: Setting the Research Agenda. International Small Business Journal, 26(3), 351-389. https://doi.org/10.1177/2F0266242608088743.

Soedjono. (2005). Pengaruh Budaya Organisasi terhadap Kinerja Organisasi dan Kepuasan Kerja Karyawan pada Terminal Penumpang Umum di Surabaya. Jurnal Manajemen dan Kewirausahaan, 7(1). 
Solekhan, \& Winarso, R. (2016). Pemanfaatan media sosial sebagai media pemasaran sangkar burung Di Kabupaten Kudus. Prosiding SNATIF, 445-448.

Steers, M. \& Porter, L. W. (1977). Motivation and work behavior, McGraw-Hill, International Edition.

Sugiharsono. (2008). Pengaruh kemampuan dan motivasi manajer serta gaya kepemimpinan pengurus dan budaya organisasi terhadap kinerja manajer dan keberhasilan organisasi koperasi unit desa di Daerah Istimewa Yogyakarta, Disertasi, Universitas Airlangga, Surabaya.

Sugiyono. (2013). Metode penelitian pendekatan kualitatif, kuantitatif, dan R\&D. Bandung: CV. Alfabeta.

Suprihati. (2014). Analisis faktor-faktor yang mempengaruhi kinerja karyawan perusahaan Sari Jati di Sragen, Jurnal Paradigma, 12(1), 93-112.

Warmayana, I. G. A. K. (2018). "Pemanfaatan teknologi informasi dan komunikasi (TIK) dalam meningkatan mutu perguruan tinggi agama hindu. Jurnal Penjaminan Mutu, 40(2), 219-226.

Zameer, H., Ali, S., Nisar, W., \& Amir, M. (2014). The impact of the motivation on the employee's performance in beverage industry of Pakistan. International Journal of Academic Research in Accounting, Finance and Management Sciences, 4(1), 29-298.

Zeng, B. \& Gerritsen, R. (2014). What do we know about social media in tourism? A review. Tourism Management Perspectives, 10, 27-36. https://doi.org/10.1016/j.tmp.2014.01.001. 